\title{
31. TERRIGENOUS SILT AND CLAY FACIES: DEPOSITS OF THE EARLY PHASE OF OCEAN BASIN EVOLUTION
}

\author{
Peter B. Andrews, Sedimentation Laboratory, New Zealand Geological Survey, Christchurch, New Zealand \\ and \\ A. Thomas Ovenshine, United States Geological Survey, Menlo Park, California
}

\begin{abstract}
A terrigenous silt and clay facies has been shown to be the first sediment to accumulate on basement (both oceanic and continental) at many sites drilled during Leg 29, and at many DSDP sites in the Indian Ocean and Tasman Sea drilled during earlier legs. It is divided into two subfacies: a burrow-mottled subfacies which predominates and a bedded subfacies which is rare.

The burrow mottled subfacies is dark olive-gray to dark brown, burrow mottled, organic-rich, pyrite, glauconite, and micronodulebearing. It is a poorly sorted, clayey silt to clay, composed of landderived detritus, and is characterized by a very restricted flora and fauna, the latter being dominated by siliceous, and agglutinating benthonic foraminifera. The upper third of the subfacies is silicified wherever the overlying sediments are rich in siliceous microfossils. It is inferred that the subfacies accumulated where bottom waters were oxygenated, but circulation was sluggish. It is further inferred that the subfacies accumulated during the early sea-floor-spreading phase in the evolution of the respective ocean basins.

The bedded subfacies forms units that alternate with the burrow mottled subfacies at one site. It consists of slightly graded beds clayey silt. The microfossils are shallow-water benthonic foraminifera and neritic nannofossils. Graded beds are interpreted as turbidites.
\end{abstract}

\section{INTRODUCTION}

Units of the terrigenous silt and clay facies occur at four of the Leg 29 sites (Figure 1), and comprise the bulk of the sequence cored at three of the sites. At all four sites the silt and clay facies forms the basal part of the sequence (Figure 2). It is Late Cretaceous in age at Site 275 , Eocene at Site 280, late Eocene and Oligocene at Site 282, and Paleocene and Eocene at Site 283. Terrigenous silt and clay also formed the basal part of the sequence at many sites drilled in the Tasman Sea and Indian Ocean during DSDP Legs 21, 22, 25, 26, and 27 (Table 1). At most of these localities the terrigenous silt and clay is Cretaceous to Eocene in age. However, at one locality (Site 261) it is Late Jurassic, and at two localities (Sites 250 and 257 in the Indian Ocean) it ranges up into the Pliocene or Quaternary. In midlatitude and subtropical locations in the Indian Ocean, Tasman Sea, and southwest Pacific Ocean the terrigenous silt and clay facies is the first sediment to accumulate on newly formed basaltic oceanic crust. In addition, at places it is the first sediment to accumulate the outer edge of deep plateaus underlain by continental crust (Sites 207 and 275). Its widespread occurrence in such positions must have paleogeographic and paleooceanographic significance.

\section{FACIES CHARACTERISTICS}

As its descriptive name implies, the facies consists predominantly of silt and clay eroded from exposed landmasses. Microfossils are either largely or entirely absent, and macrofossils are extremely rare. The facies is divided into two subfacies on the basis of visible sedimentary structures. The most common subfacies is characterized by burrow-mottling. The second subfacies is less common and distinguished by thin bedding that at places is subtly graded (more accurately described as color banding). These subfacies occur at both shallow and deep marine sites. At Site 282 units of the burrowmottled subfacies alternate with units of the bedded subfacies.

\section{Burrow-mottled Subfacies}

This subfacies occurs over the southern Lord Howe Rise (Site 207, Leg 21), at the edge of the Campbell Plateau (Site 275), at the foot of the South Tasman Rise (Sites 280 and 282), and in the central Tasman Sea (Site 283. At Site 207 the subfacies rests on continental crust of subaerial rhyolite flows and tuffs (Burns et al., 1973). At Site 275, although the base of the sequence was not reached, it is known to rest on continental crust (Summerhayes, 1969). Basement rock at other sites is listed in Table 1. 


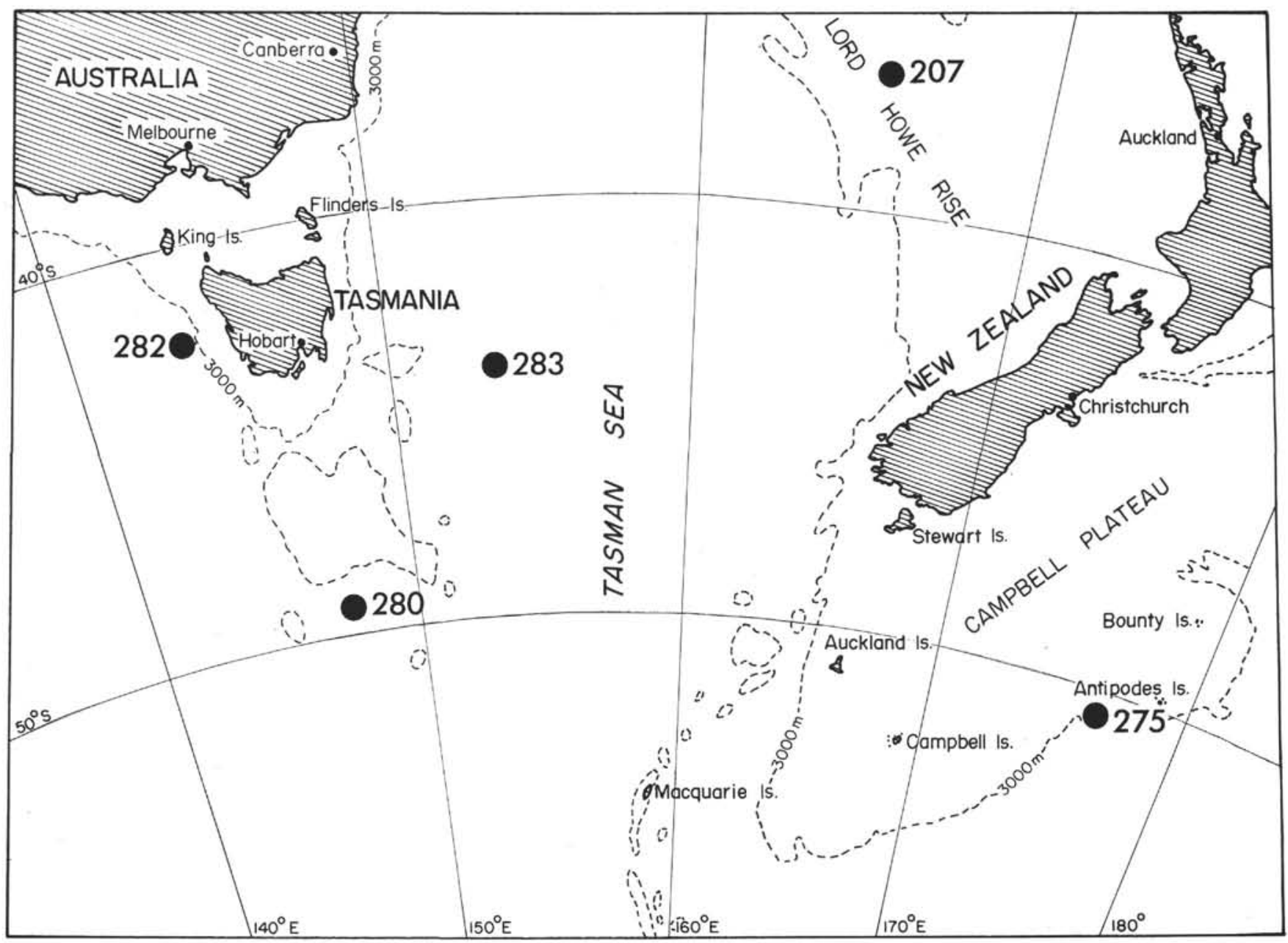

Figure 1. Location of drill sites discussed in detail; Site 207 - Leg 21; Sites 275, 280, 282, and 283 - Leg 29.

The subfacies has color variations of green-gray, olive, dark olive-gray, gray-brown, dark brown, or olive-black. The dark brown colors are characteristic of the lower part of the sequence at Sites 280,282, and 283, and the entire sequence at Site 207. The sediments are generally burrow-mottled, however, they range from massive to sparsely mottled, to intensely mottled, or to homogeneous. The intensity and distribution of mottling varies stratigraphically, however, moderate to intense mottling predominates (Figure 3). It most commonly takes the form of subhorizontal, discontinuous, or wispy irregular lamination, that gives the lower parts of a sequence a pronounced subhorizontal fabric (Figure 4). The irregular lamination is interpreted to represent compressed elliptical burrows, because individual laminations commonly transect both "older" and "younger" layers (see also Luyendyk et al., 1972). However, some subhorizontal discontinuous lamination (Site 275) cannot be shown to be of burrow origin, and thus a current origin cannot be discounted.

At Site 280 lenticular lamination occurs at one horizon low in the sequence and is regarded as current lamination. Silt and clay lamination occurs in a thin $(<1.0 \mathrm{~m})$ zone of penecontemporaneously deformed sediment just above the intrusive basalt at the site. This is probably depositional in origin, rather than the product of soft sediment flowage (Figure 5). Rare 1-4$\mathrm{cm}$ beds at Site 282 probably reflect short-term variations in sediment supply. With these possible exceptions, the subfacies is characterized by burrowmottling.

Where individual burrows are outlined, they take one of five forms. The most common are elongate $(5 \times 20$ $\mathrm{mm}$ ) horizontal to vertical tapering, elliptical burrows, lacking internal structures. Subequant blotches (20-100 $\mathrm{mm}$ diameter), with diffuse and irregular margins, are also common. Distinctive vertical or oblique elliptical burrows up to $100 \mathrm{~mm}$ diameter, and with stubby paired lateral galleries, are found sparsely distributed at two sites $(280,283)$. Slender $(1-2 \mathrm{~mm}$ wide) vertical tubes also occur in limited numbers at both sites. Large, angular, subhorizontal, and stratiform mottles, that occur in small numbers at Site 280 , appear to be modified thin beds, rather than mottles. 


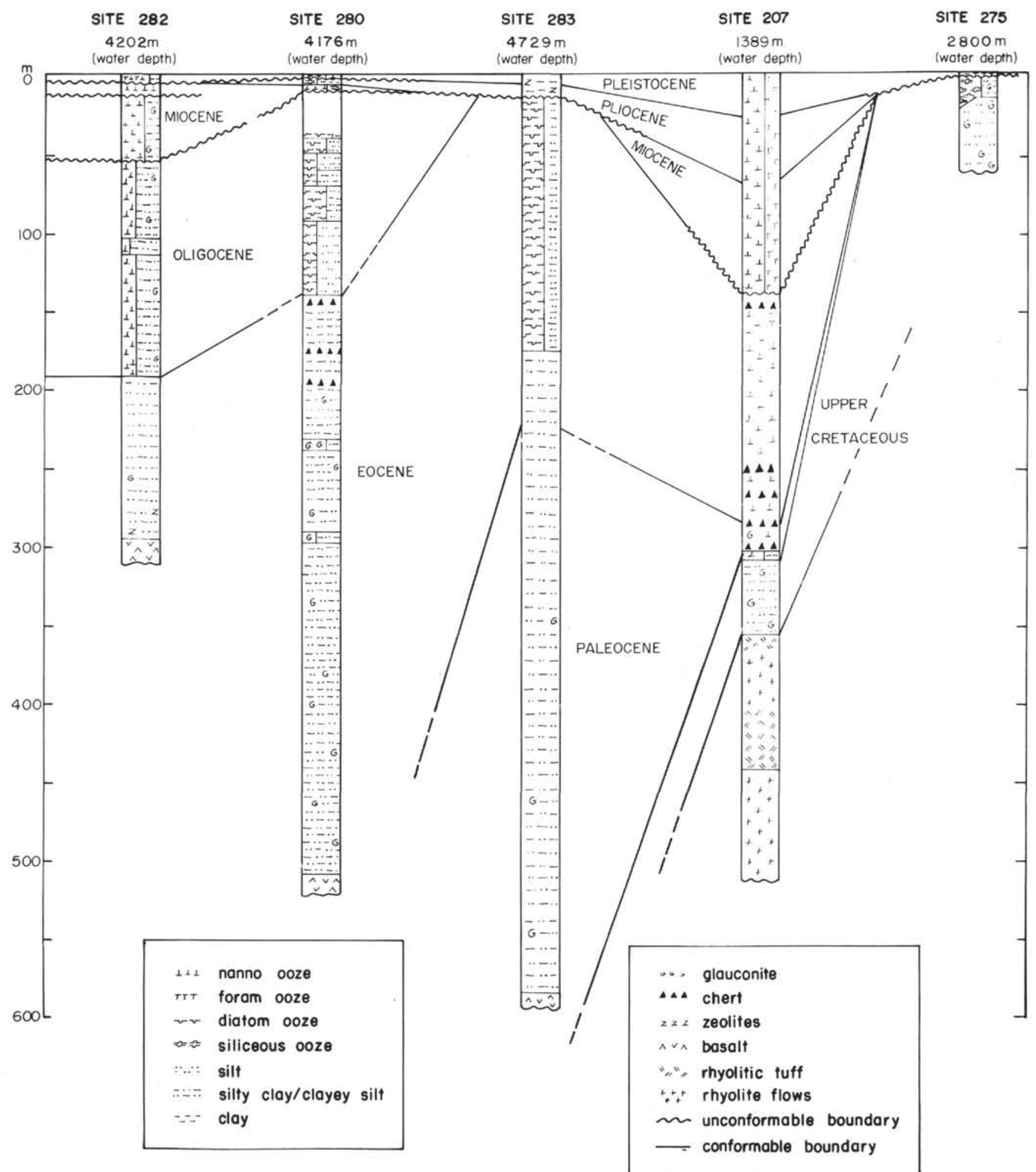

Figure 2. Stratigraphy at the sites discussed in detail; Site 207 - Leg 21; Sites 275, 280, 282, and 283 - Leg 29. 
TABLE 1

DSDP Sites Referred to in This Report

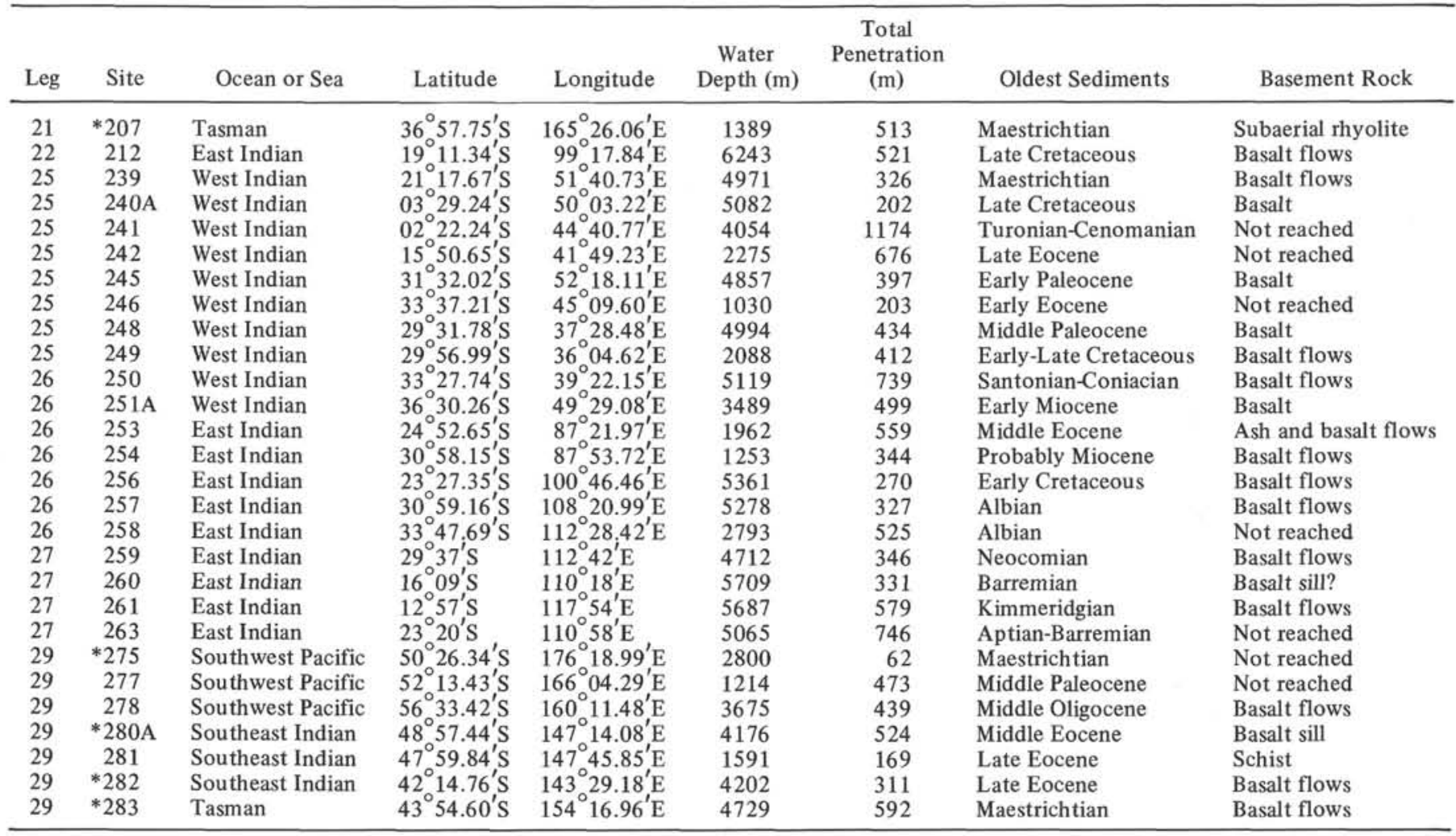

Note: Asterisked samples provide most of information discussed.

Individual burrow mottles (Figure 4) stand out because their color contrasts with that of the surrounding sediment. In some cases the color contrast reflects concentration in the mottles of dark minerals such as glauconite, pyritized material, micronodules, or mineralized diatoms. Mineralized diatoms occur at the top of the subfacies at several sites. They are the source of the dark color of tiny spot-like, and wispy mottles.

The common occurrence of burrow mottling indicates the presence of an abundant and active infauna during sediment deposition. Skeletal remains are not found, but the abundant presence of organic carbon throughout the subfacies lends support to this conclusion. Examples of this organic carbon content are: Sites 275 (one measurement, $0.9 \%$ ), 280 (values average $0.5 \%$ throughout, and measure $0.6 \%-2.2 \%$ in the lower $180 \mathrm{~m}$ ), 282 (values range from $2.4 \%$ to $5.7 \%$ ), and 283 (values range from $0.1 \%$ to $0.7 \%$, and average $0.4 \%$ ).

\section{SEDIMENT TEXTURE}

The subfacies consists predominantly of silty clay, with clay, and clayey silt subordinate (Figure 6). Sandsilt-clay sediments are confined to a thin transition zone between the terrigenous facies and the overlying siliceous ooze at Site 275 .

The sediments are very poorly sorted (Figure 7), with the bulk of a sample subequally distributed over the silt and clay size range (Table 2). Some samples are bimodal, with a minor secondary mode in the fine sand to coarse silt range.

Sediments that are the most remote from land, both at present, and at the time of deposition, are finest, and those closest to land are coarsest. Specific examples include: Site 283, central Tasman Sea, clay and silty clay; Site 280, at the foot of the South Tasman Rise, silty clay and clayey silt facies; and at both Site 275 on the outer edge of the Campbell Plateau, and Site 282 at the foot of the continental slope west of Tasmania, the sediments consist of silty clay, in which the percentage of sand is greater than at most other sites (Figure 6). This gradual decrease in size with distance from existing continental landmasses suggests that the sediments originated as land-derived detritus. The sediment was very gradually transported in suspension, and by various bottom currents, toward the deep-ocean basins.

\section{Mineralogy}

The sediment mineralogy is largely consistent with derivation from continental rocks. X-ray diffraction analysis results are presented in Table 3 . Examination of sieved fractions show that sand-size particles generally include the same range of minerals. Sieve fractions also show that the mica recognized by X-ray diffraction consists of biotite, muscovite, and schistose rock fragments. Sedimentary rock fragments (siltstone and chert) are a 

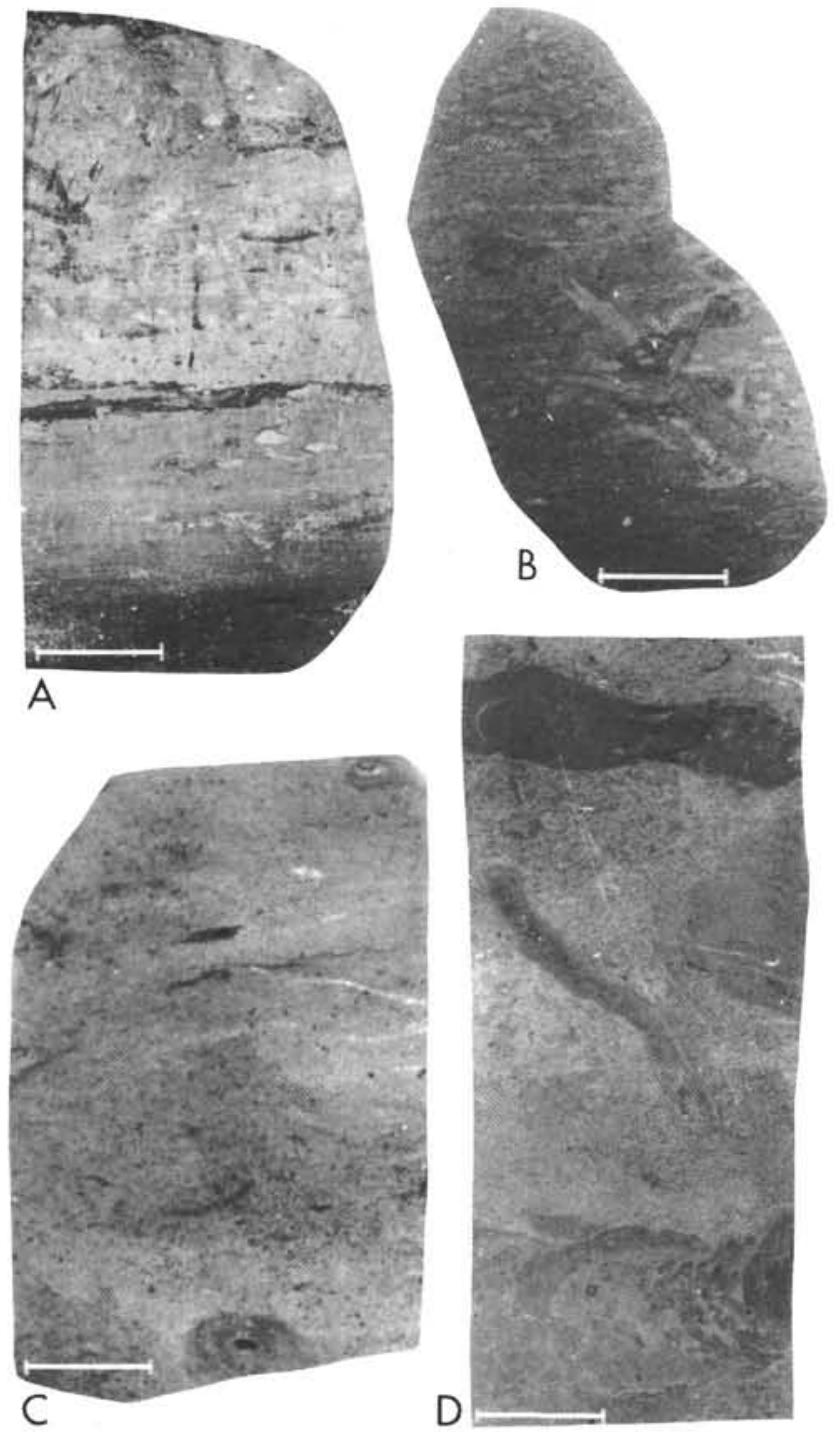

Figure 3. Slabbed core sections showing the intensity of burrowing characteristic of the burrow-mottled subfacies. The bar is $1 \mathrm{~cm}$ long. (a) Sample 29-280A-9-1, 47-50 cm; (b) Sample 29-275-4-1, 117-123 cm; (c) Sample 29-280A10-1, 102-107 cm; (d) Sample 29-280A-10-1, 75-80 cm.

notable component in the vicinity of the South Tasman Rise and Tasmania.

The authigenic minerals, glauconite, manganese or iron micronodules, and pyrite, occur throughout the subfacies. Volcanic glass, palagonite, zeolites, dolomite, gypsum, barite, and basaltic rock fragments are sparse or rare and irregularly distributed.

Glauconite, occurring in amounts ranging from a trace to $15 \%$, is bright green, generally round and botry- oidal, and sand to coarse silt size. Some grains are rectangular to irregular in shape. Rare grains displayed in a thin section from Core 280A-12-1, probably formed by the alteration of mica (see also Dudley and Margolis, this volume). Scattered grains of glauconite, including some botryoidal forms have developed by the infilling and mineralization of siliceous microfossils, especially diatoms (Sites 275 and 280). However, a study of thin sections suggests that most glauconite grains have originated by mineralization of clay minerals in the silty clay host sediment.

At one horizon in the upper part of the subfacies at Site 280 , glauconite is so abundant that the sediment is a greensand. Glauconite forms $45 \%-69 \%$ of this greensand which is a layer $34 \mathrm{~cm}$ thick at 235 meters subbottom. The bright green botryoidal glauconite occurs in a silty clay matrix. At 292 meters, a second distinctive glauconitic silty sandstone forms a bed approximately $20 \mathrm{~cm}$ thick. This bed is unusual in that it is graded. The lower $10 \mathrm{~cm}$ includes many $3-10-\mathrm{mm}$ diameter rounded clasts of pale to dark green (glauconitized?) claystone (Figure 8). Sand and coarse silt-size quartz, micas, plagioclase, rock fragments, and fragments of probable volcanic glass occur throughout and comprise $35 \%$ of the sediment. Glauconite grains make up about $15 \%$ of the sediment. Many grains are various shades of brown and are regarded as detrital. The bed is interpreted to be a turbidite.

The diagenetic minerals pyrite and micronodules are also typical of the subfacies. Shipboard calculations from smear slides suggest that the dark brown to black, spherical micronodules occur in amounts up to $20 \%$. Thin-section study suggests that some proportion of this amount is in fact spherical framboidal pyrite. The pyrite is widespread in the subfacies. Pyrite also occurs as irregular aggregates, as pseudomorphs after fecal pellets, and in the walls of diatom skeletons. The latter occurrence was found in the upper part of the sequence at Site 275 .

A study of the clay mineral distribution shows that montmorillonite is most abundant at the deep-ocean sites and least abundant at the submerged plateau sites (especially Site 275). This distribution is probably more consistent with a volcanic origin than a tropical weathering origin, the two origins of montmorillonite in oceanic sediments cited by Lisitzin (1972). The distribution and relative abundance of chlorite and kaolin is largely controlled by latitude in modern oceanic sediments. At present, chlorite is most abundant in high latitudes and kaolin is most abundant at tropical latitudes (Lisitzin, 1972). Diffraction analysis of bulk samples of the terrigenous facies shows that chlorite is absent at the northernmost sites $\left(\cong 35^{\circ}-40^{\circ} \mathrm{S}\right.$, Sites 207 and 282) and relatively abundant at the two most southern sites $\left(\cong 50^{\circ} \mathrm{S}\right.$, Sites 280 and 275$)$. Conversely, with the exception of Site 207, kaolin is most abundant at the northernmost site and decreases in relative abundance until rare at Site 280 . Kaolin is absent at the most southerly site (275). In light of these trends, the absence of kaolin at Site 207 is puzzling. 


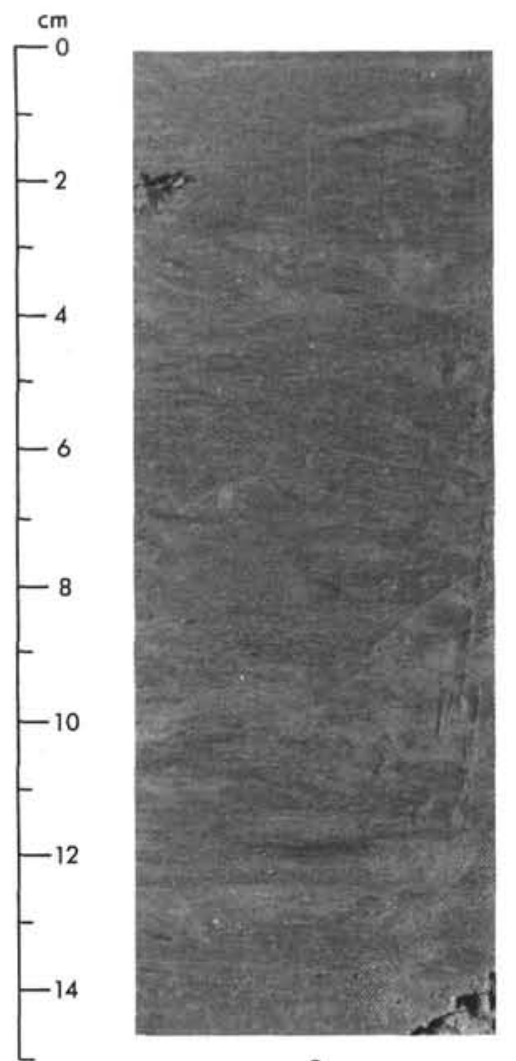

A

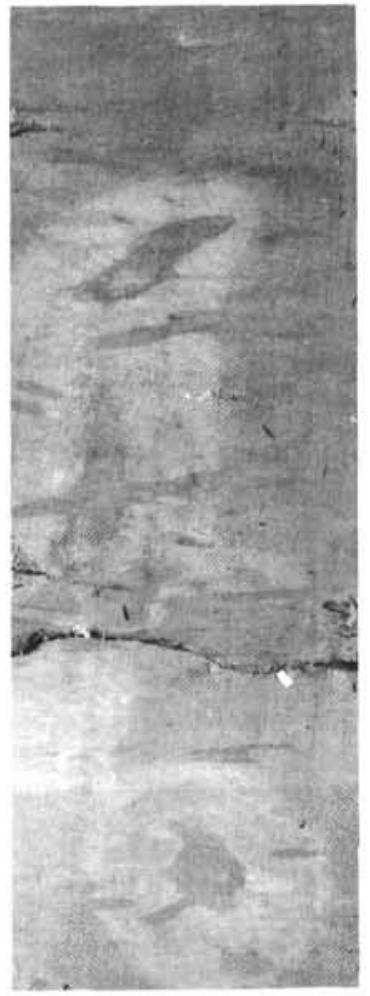

B

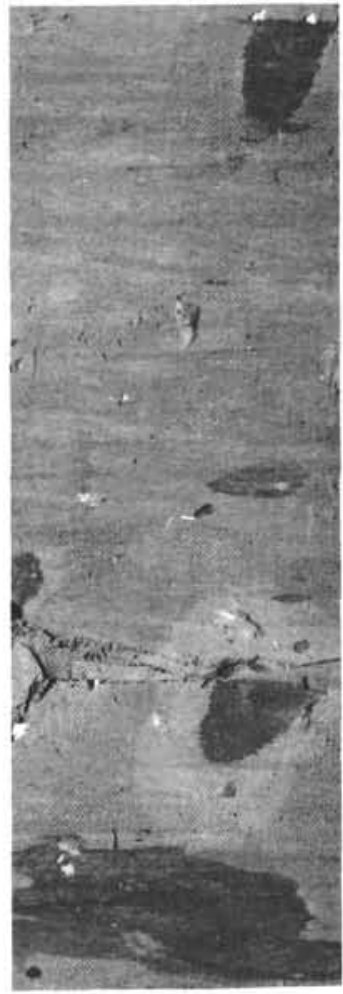

C

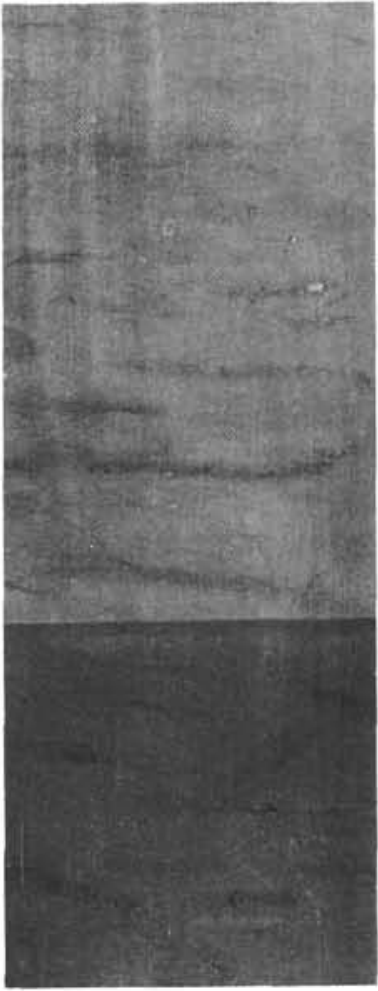

D

Figure 4. Core sections of the burrow-mottled subfacies. (a) Subhorizontal, discontinuous, and irregular lamination; interpreted to represent compressed elliptical burrows. Sample 29-280A-17-5, 25.5-40 cm; (b) Burrows (circular cross-section, tubular long-section) with lateral galleries; bleached zone around each burrow. Sample 29-280A-19-4, 80-95 cm; (c) Stratiform mottle; possibly a deformed bed of clay (lower); flat-topped burrow mottles (top and lower third). Sample 29-280A19-2, 56-72 cm; (d) Subhorizontal elliptical burrows; marked by concentrations of glauconite. Sample 29-280A-13-2, $17.5-32.5 \mathrm{~cm}$.

\section{Silicification}

The upper part of the subfacies is characteristically silicified wherever the overlying sediments are rich in scliceous microfossils. The silicified zone is rich in the secondary silica minerals, cristobalite and tridymite (Figure 9 and Table 3). In some sequences the silicified zone is stiff to semilithified, but where silicification is most advanced, for example, Site 280 , the sediment is thoroughly cemented and cannot be disaggregated, even by sonic treatment. The topmost part of the subfacies is chertified.

At Site 280, and to a lesser extent at Site 283, there is a progressive change upward from semilithified silt and clay, to silicified silt and clay rich in cristobalite and tridymite, to interbedded chert and silicified silt and clay, and finally to siliceous ooze. This progression provides stratigraphic documentation that chertification of marine muds rich in siliceous microfossils involves dissolution of the microfossils, especially diatoms. The dissolution is succeeded by precipitation of the silica to form cristobalite and tridymite and a gradual inversion of the cristobalite and tridymite to microcrystalline quartz (chert). An identical paragenesis has previously been proposed based on general observation (Berger and von Rad, 1972) and experimental work (Greenwood, 1973).

Silicification is absent and the secondary minerals cristobalite and tridymite are absent from terrigenous silt and clay that contains calcareous fossils rather than siliceous microfossils, and which is overlain by calcareous ooze, rather than siliceous ooze (for example, Site 282).

\section{Fauna and Flora}

The presence of a relatively diverse soft-bodied burrowing infauna has been inferred. In light of this, it is surprising that at all sites (except 282) the epibenthic and planktonic fauna and flora are so restricted, at least 


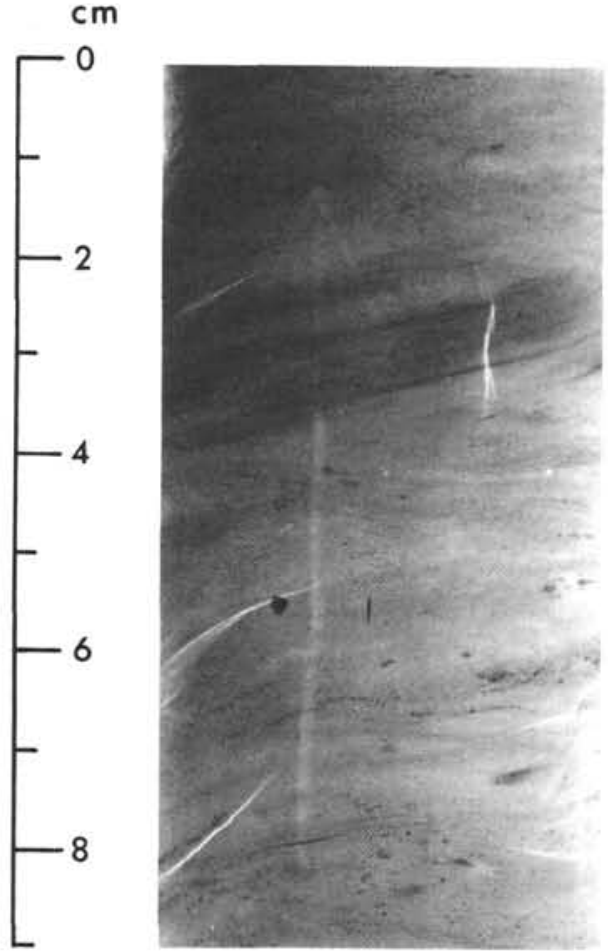

Figure 5. Radiograph of cross-laminated clayey silt; from zone of penecontemporaneously deformed sediment that lies just above the contact with the intrusive basalt; natural scale. Sample 29-280A-21-2, $54-63 \mathrm{~cm}$.

until the later stages of terrigenous sediment accumulation. The subfacies at Site 282 is exceptional in that it contains sparse amounts of sponge spicules $(6 \%$ on average), and nannoplankton (3\%-13\%, according to carbonate analyses). The nannoplankton are poorly preserved, diverse at some horizons, yet very restricted at many others. At Site 282 the subfacies is also notable for the scattered occurrence of rare bivalve fragments, a solitary coral, shallow-water benthonic foraminifera and low diversity planktonic foraminifera.

Elsewhere the fauna and flora are very restricted. Agglutinating foraminifera are the only benthic organisms that occur at all sites $(207,275,280,283)$. The large tubiform foram Bathysiphon occurs in scattered numbers at Site 283 and is abundant throughout the lower 250 meters of the sequence at Site 280 , where the only other foraminifera recorded is Cyclammina. Bolivinopsis spectabilis, several specimens of which occur at one horizon, is the only foraminifera known at Site 275. Small numbers of siliceous and agglutinating foraminifera occur throughout the sequence at Site 283, with their preservation improving and diversity increasing downward (Webb, this volume). The only other benthic fossil recovered was a small colonial worm-like to coneshaped chitinous microfossil of unknown affinity. This microfossil occurs at the base of the sequence at Site 280 and at several horizons at Site 283. The smaller specimens tended to be attached to sand grains (PerchNielsen, Chapter 25, this volume).

Pelagic microfossils including dinoflagellates, silicoflagellates, archeomonads, spores, and pollen occur in modest numbers and varying diversity at several horizons at most sites. Rare well-preserved Radiolaria occur at Site 275. Planktonic foraminifera are absent. Nannofossils also are absent, except at Site 280, where small nannofossils representing a very limited number of taxa occur sporadically.

The bulk of the subfacies is therefore characterized by a very restricted epibenthic and planktonic fauna and flora. At Sites 275, 280, and 283 the characterization changes in the upper part of the terrigenous-rich sequence. Siliceous microfossils, particularly diatoms, but also radiolarians and sponge spicules, appear in increasing amounts. At the top of the sequence at Site 275 , the microfauna is diverse, but the specimens are almost all broken. At Site 280, diatoms are rare, commonly dissolved or pyritized in the chertified upper part of the subfacies, but dinoflagellates, pollens, and spores are rich at some horizons. At Site 283 diatoms, radiolarians, silicoflagellates, and sponge spicules are few and poorly preserved over the upper 100 meters of the subfacies. However, they become increasingly diverse and the assemblage rich and moderately to well preserved over the uppermost 20-30 meters. At all three sites, this transition zone is succeeded by terrigenous siliceous oozes, in which well-preserved diatoms are dominant. At Site 207, the terrigenous facies grades upward into clay-rich nannofossil chalk, then chertified chalk, then siliceous fossil-bearing foraminiferal and nannofossil ooze.

Thus, at the four sites $(275,280,283$, and 297$)$ there is a rapid deterioration in skeleton condition and numbers down-section until the sequence becomes barren of siliceous microfossils. This is interpreted to be directly linked to their dissolution and the precipitation of the secondary silica minerals, cristobalite and tridymite. It is apparent that the upper and even the middle parts of the deposited sequence were either siliceous-rich silty clay or silty clay-rich siliceous ooze. It is not clear whether the nonsilicified lower part of the sequence accumulated in the form of siliceous-rich silty clay, or as just a relatively nonfossiliferous silty clay. Two sites have provided a detailed sediment record down to basement $(280,283)$, and most of the siliceous and agglutinating benthic foraminifera that occur in the sequences, especially the striking and large Bathysiphon, come from below the silicified zone of terrigenous sediments. It could be argued that the initial deposits were largely barren of siliceous microfossils, and the lower limit of silicification represents the point in the sequence at which biogenically productive cool ("Antarctic") water rich in siliceous micro-organisms reached each site. This interpretation is preferred. 


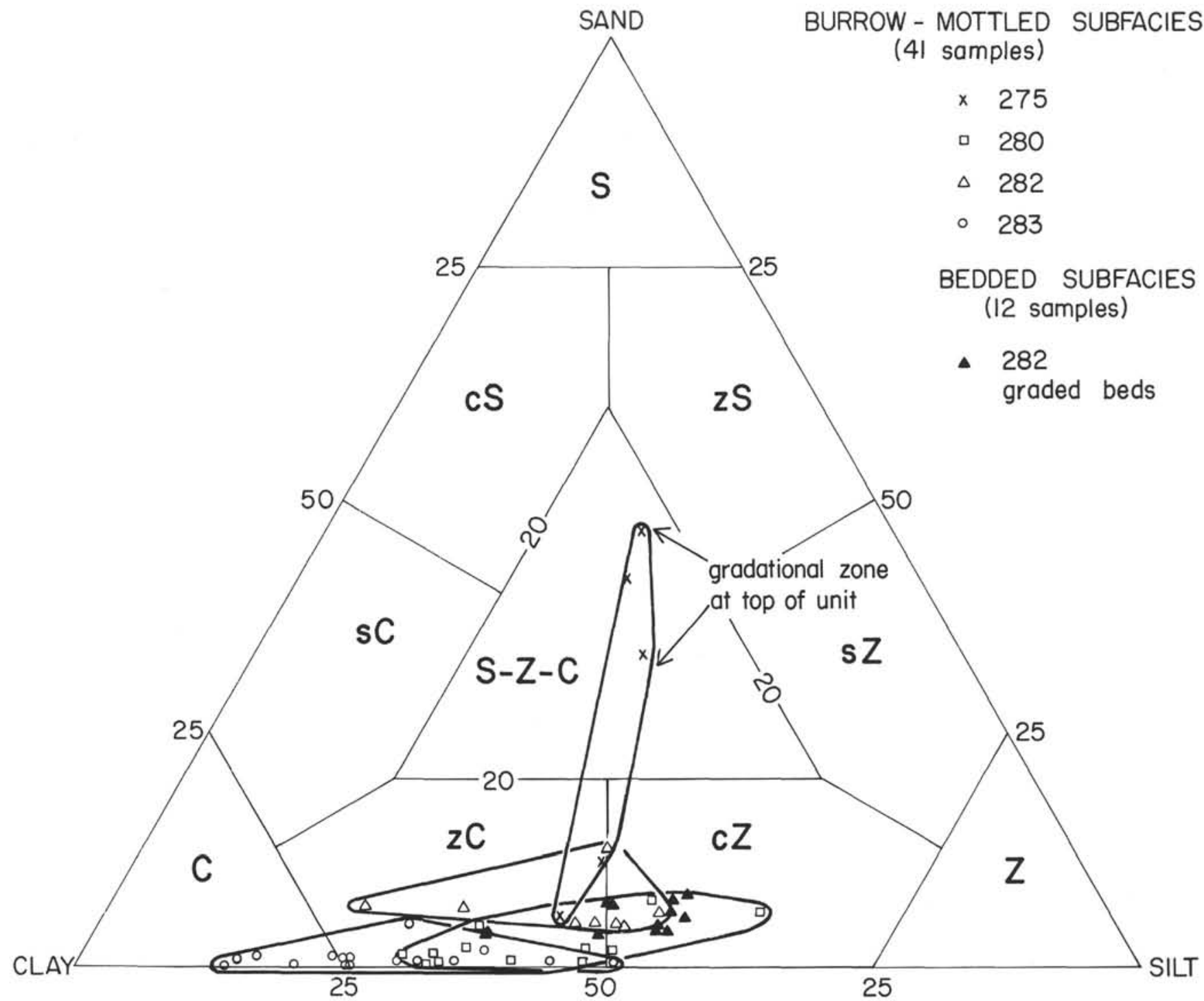

Figure 6. Ternary sand-silt-clay diagram showing the textural characteristics of the burrow-mottled and the bedded subfacies. The three coarse samples come from a transitional zone where terrigenous silt and clay grades up into radiolarian-rich diatom ooze at Site 275.

\section{Depositional Conditions}

The burrow-mottled terrigenous silt and clay subfacies is widespread in the Southern Oceans in a variety of bathymetric positions. At many locations it is the first sediment deposited upon basement (largely newly formed oceanic basalt, but at a few locations continental crust). The main feature that must be explained is the almost total absence of the planktonic microfossils that elsewhere dominate oceanic sediments.

Burrow-mottles of various forms suggest that a diverse and relatively abundant infauna existed, a conclusion supported by the high concentration of organic carbon and the widespread occurrence of pyrite, some pseudomorphous after fecal pellets. These features suggest that the environment of deposition was moderately oxygenated, and certainly not euxinic. The overlying waters were oxygenated, and possibly moderately agitated. This is indicated by the characteristic occurrence of manganese micronodules throughout the subfacies; micronodules do not form in stagnant waters. However, the bottom currents responsible for water agitation must have been weak, as primary stratification is rare. Sparse stratification may have been destroyed by the burrowing infauna, but many sections are only slightly burrowed, so that any original primary stratification would still be visible.

The very restricted nature of the epibenthic microfauna further suggests that bottom water conditions were ecologically limiting. The almost total absence of planktonic calcareous microflora and microfauna (except at Site 282) probably means that the depositional sites lay below the carbonate compensation depth. High 


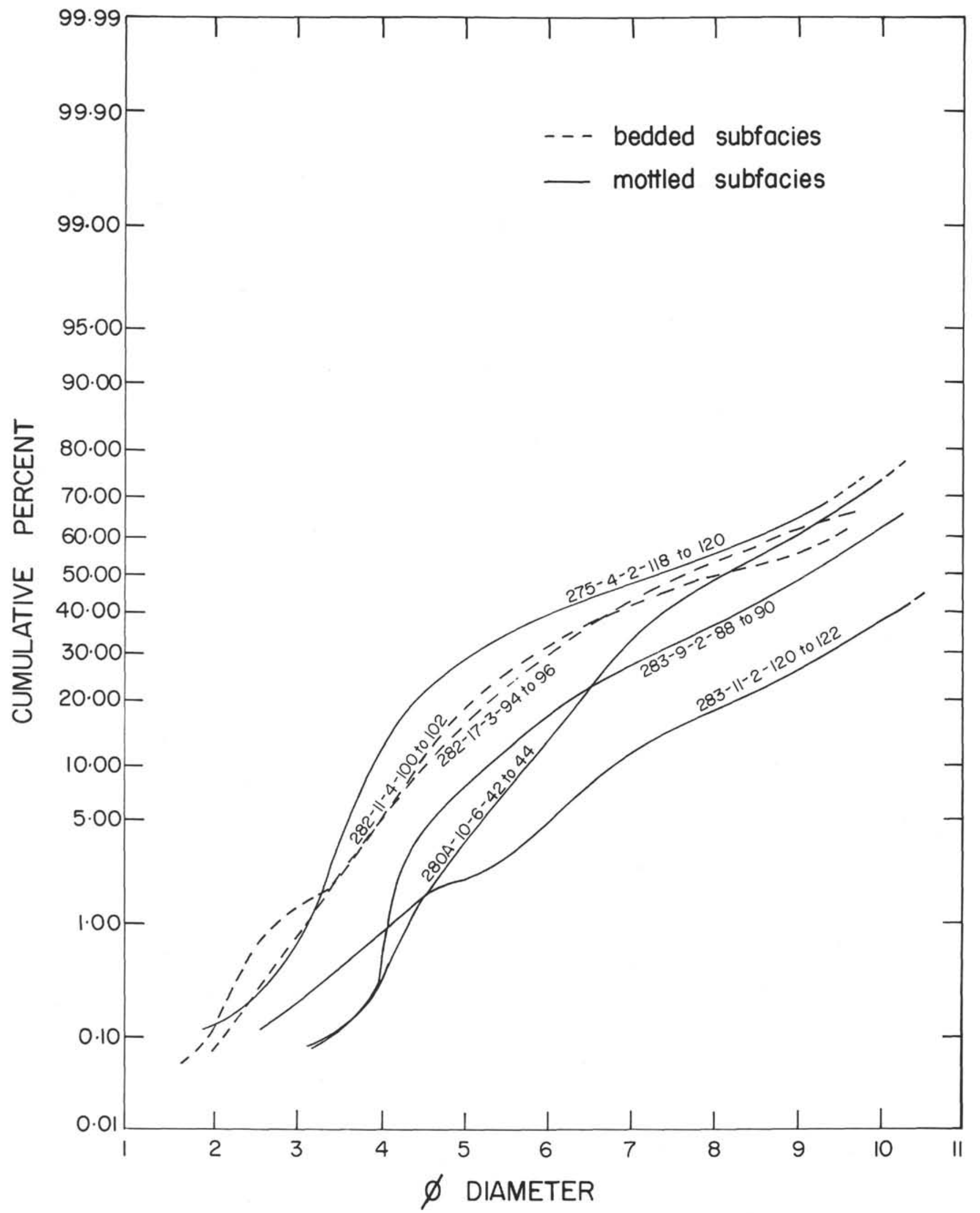

Figure 7. Cumulative frequency curves showing the grain size distribution in a characteristic range of samples from the two subfacies. 
TABLE 2

Sand-Silt-Clay Proportions and Median Size Values for Samples from the Burrow-Mottled Subfacies

\begin{tabular}{|c|c|c|c|c|c|}
\hline $\begin{array}{c}\text { Sample } \\
\text { (Interval in } \mathrm{cm} \text { ) }\end{array}$ & $\begin{array}{l}\text { Sand } \\
(\%)\end{array}$ & $\begin{array}{l}\text { Silt } \\
(\%)\end{array}$ & $\begin{array}{l}\text { Clay } \\
(\%)\end{array}$ & $\begin{array}{l}\text { Median } \\
\left(\phi_{50}\right)\end{array}$ & Classification \\
\hline$* 275-2-6,60$ & 41.5 & 31.0 & 27.5 & 4.26 & Sand-silt-clay \\
\hline $275-2-6,101$ & 33.1 & 36.8 & 30.1 & - & Sand-silt-clay ${ }^{\mathrm{a}}$ \\
\hline$* 275-2-6,136$ & 46.5 & 29.9 & 23.6 & 4.09 & Sand-silt-clay ${ }^{a}$ \\
\hline $275-4-2,112$ & 5.1 & 42.9 & 52.0 & - & Silty clay \\
\hline$* 275-4-2,118$ & 11.3 & 43.5 & 45.2 & 7.40 & Silty clay \\
\hline$* 280 \mathrm{~A}-8-2,116$ & 0.0 & 32.5 & 67.5 & 10.05 & Silty clay \\
\hline *280A-10-6, 42 & 0.3 & 47.6 & 52.1 & 8.20 & Silty clay \\
\hline $280 \mathrm{~A}-10-6,57$ & 0.1 & 40.9 & 59.0 & - & Silty clay \\
\hline *280A-13-3, 57 & 5.6 & 61.3 & 33.1 & 6.42 & Clayey silt \\
\hline $280 \mathrm{~A}-14-1,78$ & 27.8 & 19.5 & 52.7 & - & Glauconitic sandy clay \\
\hline$* 280 \mathrm{~A}-15-2,20$ & 8.5 & 79.1 & 12.4 & 4.80 & Silt \\
\hline $280 \mathrm{~A}-17-1,88$ & 0.7 & 33.2 & 66.2 & - & Silty clay \\
\hline$* 280 \mathrm{~A}-17-4,100$ & 1.8 & 46.9 & 51.3 & 8.10 & Silty clay \\
\hline $280 \mathrm{~A}-18-1,105$ & 1.3 & 32.6 & 66.0 & - & Silty clay \\
\hline $280 \mathrm{~A}-19-3,80$ & 4.1 & 35.1 & 60.8 & - & Silty clay \\
\hline$* 280 \mathrm{~A}-19-3,90$ & 7.1 & 50.3 & 42.6 & 7.10 & Clayey silt \\
\hline$* 280 \mathrm{~A}-20-3,130$ & 2.2 & 35.4 & 62.4 & 8.96 & Silty clay \\
\hline $280 \mathrm{~A}-21-2,116$ & 1.1 & 29.8 & 69.1 & - & Silty clay \\
\hline$* 280 \mathrm{~A}-22-1,100$ & 1.9 & 49.4 & 48.7 & 7.92 & Clayey silt \\
\hline $282-11-4,51$ & 6.7 & 23.2 & 70.0 & - & Silty clay \\
\hline *282-11-4, 100 & 4.8 & 44.2 & 51.0 & 8.16 & Silty clay \\
\hline $282-11$, CC & 6.6 & 32.9 & 60.5 & - & Silty clay \\
\hline $282-15, \mathrm{CC}$ & 12.1 & 43.8 & 44.1 & - & Silty clay \\
\hline $282-16-1,58$ & 4.9 & 46.5 & 48.6 & - & Silty clay \\
\hline *282-16-1, 78 & 5.9 & 51.7 & 42.4 & 7.20 & Clayey silt \\
\hline $282-17-3,75$ & 4.3 & 49.3 & 46.4 & - & Clayey silt \\
\hline$* 282-17-3,94$ & 4.8 & 48.8 & 46.4 & 7.66 & Clayey silt \\
\hline $283-8-2,56$ & 0.5 & 29.6 & 69.9 & - & Silty clay \\
\hline$* 283-8-2,75$ & 1.9 & 37.4 & 60.7 & 8.90 & Silty clay \\
\hline $283-9-2,68$ & 0.2 & 44.5 & 55.3 & - & Silty clay \\
\hline *283-9-2, 88 & 0.4 & 36.1 & 63.5 & 9.13 & Silty clay \\
\hline $283-11-2,84$ & 0.0 & 25.0 & 74.9 & - & Silty clay \\
\hline *283-11-2, 120 & 0.8 & 16.4 & 82.8 & 11.20 & Clay \\
\hline $283-12-2,77$ & 0.0 & 50.2 & 49.8 & - & Clayey silt \\
\hline *283-12, CC & 0.4 & 31.6 & 68.0 & 9.41 & Silty clay \\
\hline $283-13-2,75$ & 0.1 & 20.2 & 79.6 & - & Clay \\
\hline $283-14-3,55$ & 0.5 & 25.2 & 74.3 & - & Silty clay \\
\hline *283-14-3, 69 & 4.6 & 29.0 & 66.4 & 9.76 & Silty clay \\
\hline $283-15-2,78$ & 0.3 & 25.7 & 73.9 & - & Silty clay \\
\hline$* 283-16-2,89$ & 0.6 & 14.6 & 84.8 & 10.28 & Clay \\
\hline $283-16-2,106$ & 0.1 & 13.5 & 86.3 & - & Clay \\
\hline $283-17-4,83$ & 1.0 & 23.5 & 75.6 & - & Clay \\
\hline$* 283-17-4,109$ & 0.5 & 25.7 & 73.8 & 9.54 & Silty clay \\
\hline
\end{tabular}

Note: Samples marked with an asterisk were analyzed in the Sedimentation Laboratory, New Zealand Geological Survey; the remainder were analyzed by the Deep Sea Drilling Project.

${ }^{\mathrm{a}}$ Transition zone. 
TABLE 3

Mean Composition of the Terrigenous Silt and Clay Facies Based on X-Ray Diffraction Analysis of Bulk Samples

\begin{tabular}{|c|c|c|c|c|c|c|}
\hline \multirow{3}{*}{ Mineral } & \multicolumn{5}{|c|}{ Mottled Subfacies } & \multirow{3}{*}{$\begin{array}{c}\begin{array}{c}\text { Bedded } \\
\text { Subfacies }\end{array} \\
\begin{array}{c}\text { Site } \\
282\end{array} \\
(10)\end{array}$} \\
\hline & $\begin{array}{l}\text { Site } \\
207\end{array}$ & $\begin{array}{l}\text { Site } \\
275\end{array}$ & Site & $\begin{array}{l}\text { Site } \\
283\end{array}$ & Site & \\
\hline & (2) & (2) & (7) & (9) & (6) & \\
\hline Quartz & 7.1 & 33.6 & 35.9 & 32.8 & 37.2 & 28.5 \\
\hline K-feldspar & 1.4 & 14.1 & 4.3 & 3.4 & 1.7 & 2.6 \\
\hline Plagioclase & 3.0 & 8.6 & 7.2 & 2.0 & 2.5 & 4.1 \\
\hline Mica & 1.2 & 27.0 & 26.2 & 21.8 & 13.8 & 10.1 \\
\hline Montmorillonite & 3.3 & 2.6 & 13.4 & 27.8 & 11.5 & 16.7 \\
\hline Clinoptilolite & 1.1 & 1.6 & 0.8 & - & 10.3 & 0.8 \\
\hline Pyrite & 1.8 & 1.0 & 0.9 & 0.9 & 4.0 & 0.4 \\
\hline Chlorite & - & 1.4 & 3.6 & 1.7 & - & - \\
\hline Kaolin & - & - & 0.1 & 1.5 & 9.3 & 5.3 \\
\hline Gypsum & - & - & - & 0.8 & - & 0.4 \\
\hline Calcite & - & - & - & 0.2 & 9.2 & 30.2 \\
\hline Aragonite & - & - & - & - & 0.4 & 1.0 \\
\hline Cristobalite & 69.2 & 9.0 & 7.3 & 6.5 & - & - \\
\hline Tridymite & 11.4 & 1.3 & 0.2 & 0.5 & - & - \\
\hline
\end{tabular}

Note: Numbers in parentheses indicate number of samples.

detrital sedimentation rates cannot account for the absence of calcareous nannofossils in the New ZealandTasman Sea area. However, it may account for their occurrence in only limited numbers in the terrigenous silt and clay facies at many Indian Ocean sites. Because of the paucity of fossils, sedimentation rates cannot be calculated at many sites. At two sites where calculation is possible, the rates are relatively high $(8 \mathrm{~cm} / 1000 \mathrm{yr}$ at Site 263 and $4 \mathrm{~cm} / 1000 \mathrm{yr}$ at Site 280).

In summary, these features suggest that the very finegrained terrigenous sediments accumulated at various oceanic sites where bottom waters were oxygenated, but circulation was sluggish. In the New Zealand-Tasman Sea area, the subfacies is succeeded upward by mixed detritus and siliceous ooze and then siliceous ooze. In much of the Indian Ocean, the subfacies is succeeded upward by nannofossil and mixed foraminiferal and nannofossil ooze. These sequences suggest that circulation in each ocean basin was restricted for a long time, but that gradually an integrated circulation pattern evolved for each basin. Cool (Antarctic) waters consequently were introduced into the southwest Pacific Ocean and the Tasman Sea, and warm (subtropical) waters were introduced into the Indian Ocean.

\section{Bedded Subfacies}

This subfacies is characterized by color-graded and slightly size-graded bedding and by varying amounts $(5 \%-15 \%)$ of nannofossils. The beds characterize units that alternate with units of the burrow-mottled subfacies. At Site 282 bedded subfacies occurs throughout two zones: one, 55-105 meters, and the other, 114-192 meters subbottom (Figure 2).

The bedded subfacies is a green-gray, light olive-gray, and olive-gray silty clay and clayey silt. Color-graded beds $20-90 \mathrm{~cm}$ thick are common, grading upward from olive-gray to green-gray, or conversely from light at the

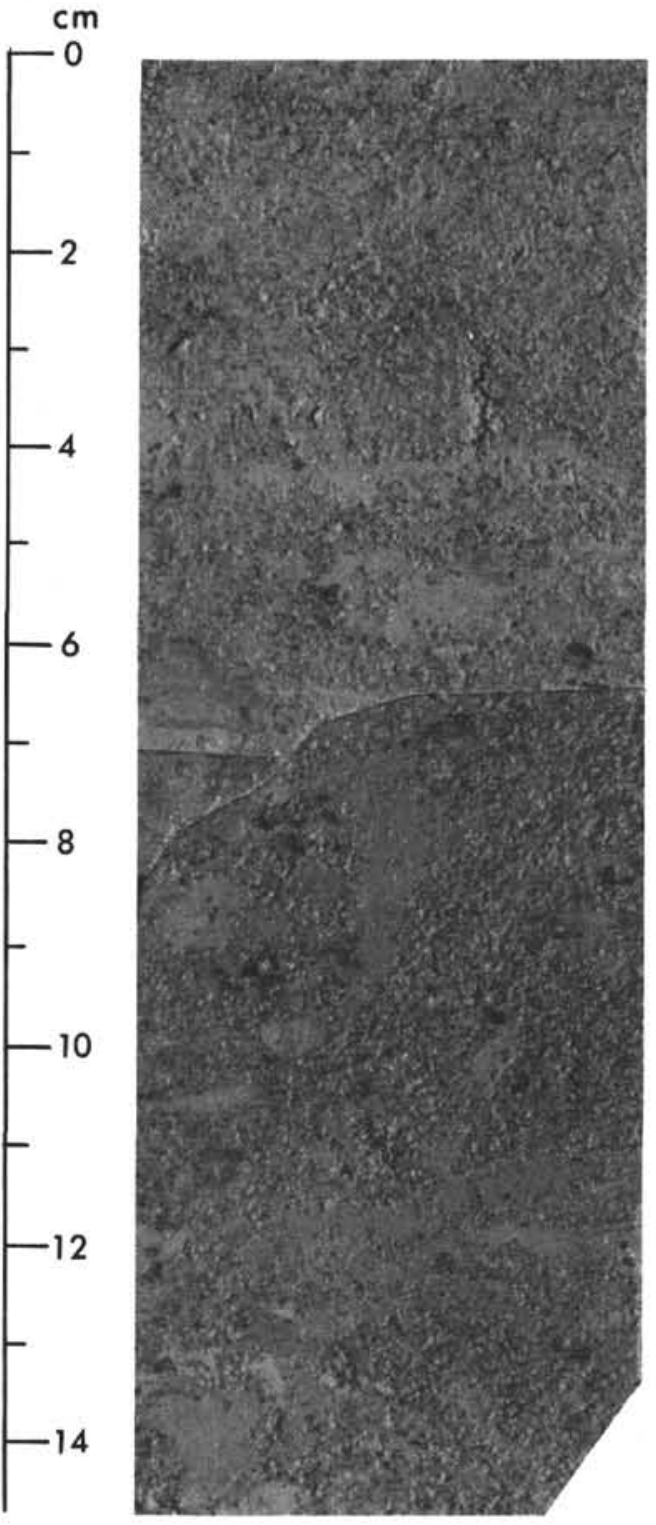

Figure 8. Part of a graded bed of glauconitic silty sandstone. Rounded clasts $13-10 \mathrm{~mm}$ diameter) of glauconitized claystone are abundant in the lower part of the bed. Sample 29-280A-14-1, 69-84 cm.

base to dark at the top. The interbed intervals are generally green-gray. Most color-graded beds are siltier than the interbed intervals, but sand content is the same (Figure 6). Detailed analysis shows that some beds are detectably size-graded (Figure 10), the lower interval being reverse graded, a common feature in graded beds. Some beds appear to be amalgamated, consisting of successive graded intervals. Nannofossil content and character appear to be markedly different between the graded beds and the interbed intervals. One detailed 


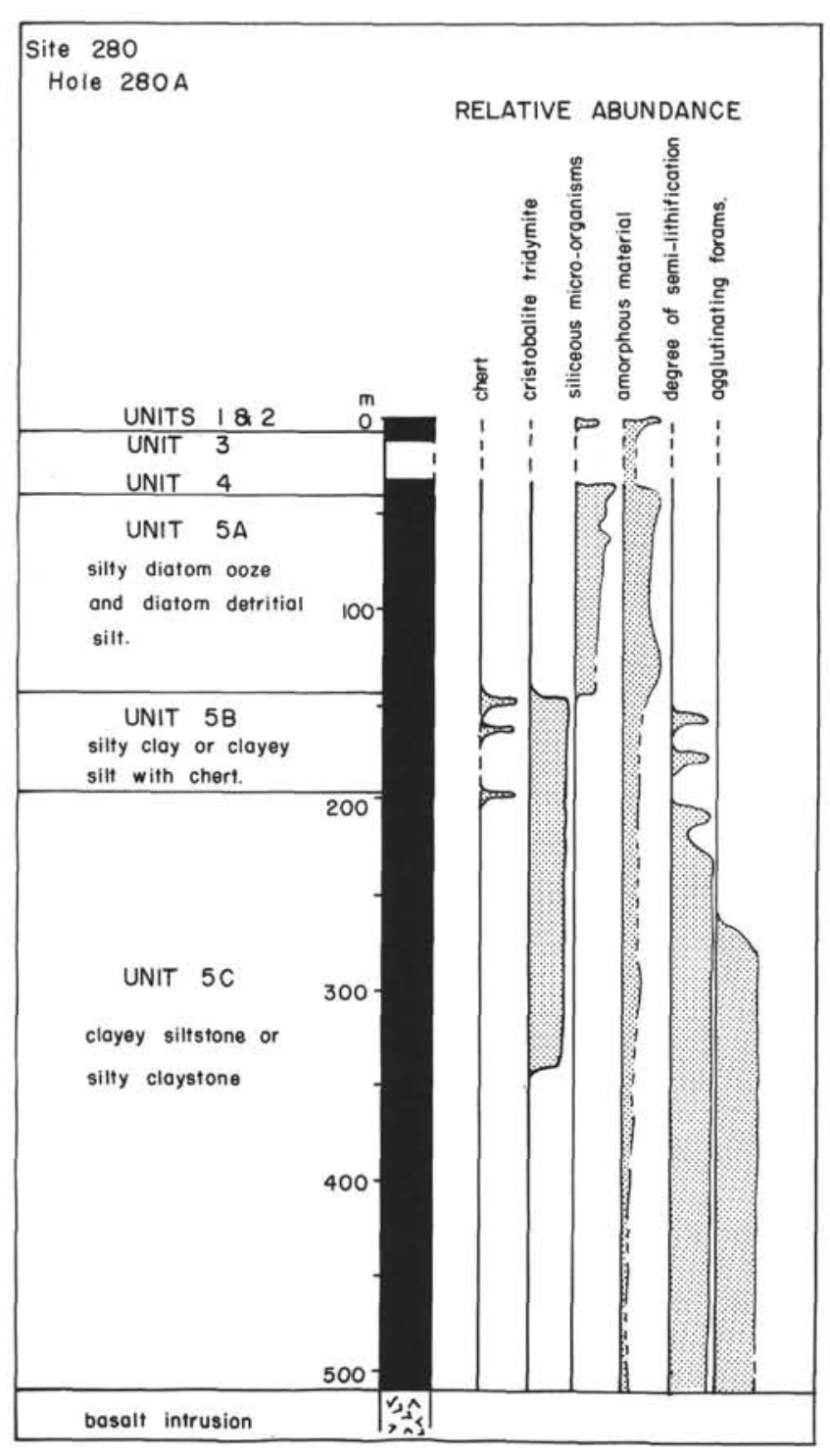

Figure 9. Sequence at Site 280. (Hole 280A), showing the relative frequency and relationship between the disappearance of siliceous microfossils and the development of silicification (expressed by the presence of chert, cristobalite, and tridymite). The relationships here provide stratigraphic evidence that siliceous microfossils provide the silica that crystallizes to form cristobalite, tridymite, and, through inversion, chert.

analysis showed that a graded bed contained abundant, moderately preserved nannofossils, whereas the interbed contained small numbers of poorly preserved nannofossils. No variation in nannofossil content or character throughout the bed could be detected.
Thin beds (1-2 cm thick) that are sparsely scattered throughout the subfacies are rich in glauconite. Some horizons are intensely mottled, the mottling all but masking thin beds, but generally the subfacies is sparsely mottled.

Carbonate analyses show that the bedded subfacies contains $15 \%-40 \%$ calcareous microfossils, most of which are nannofossils. Shallow-water microfossils form a significant part of the fossil assemblage; benthonic foraminifera, neritic nannofossils, and ascidian sclerites occur throughout. No bivalve shell fragments or solitary corals were seen.

Compositionally, the subfacies is very similar to the burrow-mottled subfacies with which it alternates. Calcium carbonate content is higher (average of $24 \%$ versus 9\%), and the sponge spicule, nannofossil, and glauconite content is markedly higher than in the burrow-mottled subfacies. Organic carbon content is much lower (average of $0.3 \%$ versus $3.3 \%$ ), pyrite significantly lower, and micronodule content very similar or slightly lower than in the mottled subfacies. The detrital mineralogy is very similar in content and proportions in both subfacies, although sand-size rock fragments and round quartz grains are notable in the bedded subfacies.

\section{Depositional Conditions}

Site 282 in 4202 meters of water is near the foot of the continental slope off western Tasmania. Its position is very similar to that of Site 280 .

The terrigenous facies at Site 282 is very similar to that at Sites 207, 275, 280, and 283, with the exception that shallow marine benthonic organisms (foraminifera, solitary corals, bivalve fragments, and ascidian sclerites) and neritic nannofossils occur in both subfacies. The color-grading, subtle size-grading, and relative abundance of nannofossils in the graded beds of the bedded subfacies suggest that they represent the periodic incursion of turbidity currents into the depositional area. The beds are regarded as distal turbidites and appear to consist largely of sediment reworked from the continental shelf and continental slope. The occurrence of shallow benthonic and neritic fossils throughout both subfacies suggests that shelf material was continually reworked into deep water at this locality. However, it was only periodically that sufficient sediment was entrained for density currents to form and distinct beds to be deposited at the foot of the continental slope. The frequency of turbidite deposition and the volume of sediment deposited appear to have been low, as the rate of sedimentation is the same for both subfacies $-2.4 \mathrm{~cm} / 1000 \mathrm{yr}$, a moderate rate.

\section{CONCLUSIONS}

The terrigenous silt and clay facies appears to be the normal sediment accumulation in moderate- to deepocean positions wherever planktonic organisms do not richly populate the overlying water column. The facies also accumulates where the depositional sites are so deep that microfossils, especially calcareous microfossils, are dissolved before they can become incorporated in the sediment. At some deep sites, calcareous sediments interbedded with terrigenous silt and 


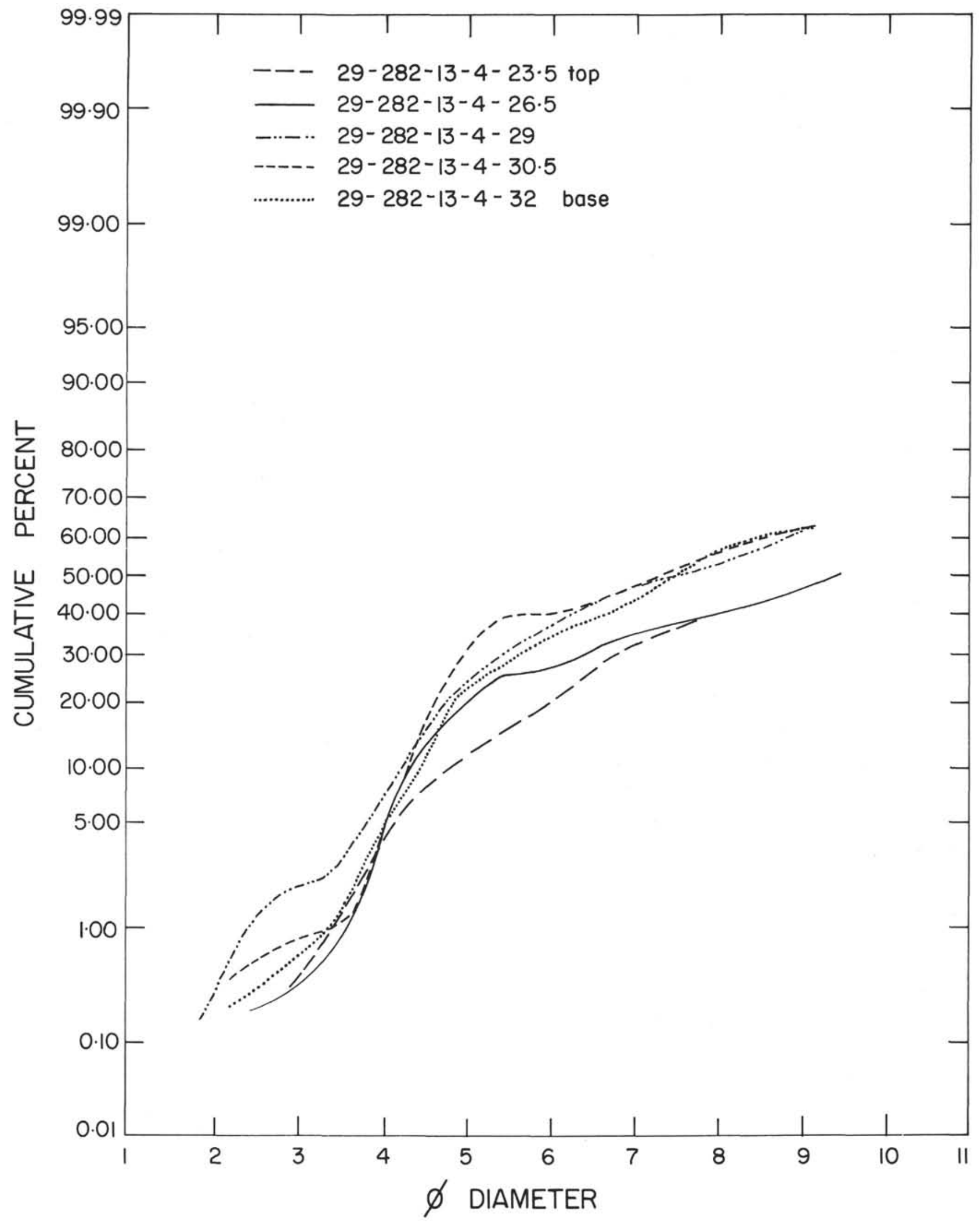

Figure 10. Cumulative size frequency curves for a series of samples showing grading in a bed from the bedded subfacies at Site 282. 
clay are interpreted to represent turbidites (Sites 212, 260 , and 282 of the Indian Ocean). Elsewhere, it is usually terrigenous sediment that accumulates upon basement. Apparently terrigenous sediment is only replaced by organic sediments, either siliceous or calcareous, when continental landmasses have drifted sufficiently far apart for an integrated circulation pattern to have developed, covering most or all of the evolving ocean basin. This sequence of events is especially clear in the areas covered by DSDP Legs 21 and 29 (Sites 207, 275 , probably $277,280,282$, and 283 ) and in large part also is applicable on both the west and east sides of the Indian Ocean (Sites 241, 248, 256, 258, 259, and 263). Wherever the sequence is dominantly organic sediment in these areas, the sequence has either formed after spreading has developed and an integrated circulation pattern evolved (Sites 240[?], 245[?], 251, 278) or it has formed on shallow topographic features whose very elevation above the surrounding topography generates a persistent local circulation that promotes biogenically rich overlying waters (Sites 242, 246, 253, 254, 277, 281, and 284). These conclusions are based largely on those sites in the western Pacific, Tasman, and Indian oceans where basement was reached, or very closely approached.

In the areas covered by Legs 21 and 29 (southwest Pacific, Tasman Sea, southeast Indian Ocean), the change from terrigenous sediments to mixed biogenic and terrigenous sediments or purely biogenic sediments appears to be closely related to the sea-floor-spreading history determined for each ocean segment. Magnetic lineation data show that the New Zealand subcontinent (including the Campbell Plateau and Lord Howe Rise) began to spread away from Antarctica about 80-83 million years ago. The New Zealand subcontinent began to spread away from Australia about 78 million years ago, and Australia began to spread away from Antarctica about 56 million years ago. The latter is about the same time that spreading in the Tasman Sea concluded (Weissel and Hayes, 1972; Christoffel and Falconer, 1972; Hayes and Ringis, 1973).

The change from terrigenous sedimentation to largely siliceous biogenic sedimentation in the vicinity of the Campbell Plateau (Site 275) began in the late Campanian 70-75 million years ago). On the southern Lord Howe Rise (Site 207) the change from terrigenous to mixed calcareous and siliceous sedimentation began at the end of the Maestrichtian, or the beginning of the Paleocene (65 million years ago). The change to siliceous sedimentation in the central Tasman Sea (Site 283) began early in the Eocene (about 54 million years ago), and the change to mixed siliceous and terrigenous sedimentation in the vicinity of the South Tasman Rise (Site 280, southeast Indian Ocean) began about the end of the Eocene ( 38 million years ago). Even if one infers that siliceous microfossils originally occurred (that is, presilicification and chertification) much lower in the sequence at each of these four sites, the depositional order is still the same, and is still consistent with the spreading history appropriate to eàch location.

This order of events lends support to the thesis that the terrigenous facies accumulated in ocean basins under limited circulation conditions. Only when the continental landmasses had drifted far apart did an integrated oceanic circulation pattern develop and an abundant and diverse plankton appear. With its appearance, terrigenous bottom sediments became diluted with siliceous microorganisms that populated the overlying oceanic waters.

\section{Probable On-Land Equivalents of the Terrigenous Facies}

Several Maestrichtian sedimentary rock units exposed in eastern New Zealand closely compare with the terrigenous facies as described and may have a similar origin. In Marlborough, South Island, the Woolshed Formation (Webb, 1971) consists of up to 750 meters of dark brown and dark gray, siliceous, pyritic carbonaceous mudstone. It is characterized by a marked parting parallel to the bedding and splintery fracture. The upper part of the unit is increasingly siliceous and at the top contains several 0.31 .7 -meter-thick bands of dark brown chertified shale (MacPherson, 1952). It is succeeded conformably by bedded chert with greensand partings (Mead Hill Flint of Webb, 1971), which in turn is conformably succeeded by a white, partly chertified fine-grained limestone (Amuri Limestone). To the northeast the Woolshed Formation grades into the Mirza Formation, Webb (1971), which is up to 300 meters thick. It is a fine-banded clayey siltstone, with scattered lenticular nodules of chert and is conformably overlain by sandstone and siltstone with chert lenses (Butt Formation). The Butt Formation is in turn succeeded by the Amuri Limestone. The Woolshed and Mirza formations are characterized by a limited fauna consisting of siliceous and agglutinated foraminifera and appear very similar to the mottled subfacies.

A third Maestrichtian unit, the Whangai Formation, which also compares closely with the terrigenous facies, is widespread in southern Hawkes Bay, North Island (Lillie, 1953; Kingma, 1971). It is a uniformly pale gray (weathers white), hard, micaceous, siliceous argillite, up to 900 meters thick. Conchoidal fracture is characteristic at some places. It is thoroughly burrowed, and fine discontinuous banding is faintly discernible at many locations. The upper part is commonly dark gray and chertified. Glauconitic mudstone and greensand are common near the top of the unit. The lower part of the unit is characterized by a restricted fauna of siliceous and agglutinating foraminifera, but the upper part contains a much more diverse fauna which includes some calcareous benthonic and planktonic foraminifera and nannofossils. The Whangai Formation is succeeded by variously colored, soft mudstone, greensand, and hard blue-gray siltstone.

The silicified character of these units may result from dissolution of siliceous microfossils, and redeposition of the silica as cristobalite and tridymite, as noted in the burrow mottled subfacies. Remnant siliceous microfossils have not been reported from the units, but Radiolaria occur in sediments overlying the Whangai Formation (Finlay, in Lillie, 1953), and large sponges are known from Amuri Limestone where it overlies Woolshed and Mead Hill formations at Woodside Creek, Marlborough. With the knowledge provided by 
Leg 29 results, careful collecting may well show that siliceous microfossils, especially diatoms, were originally characteristic of the Woolshed, Mirza, and Whangai formations, and that the sediments were deposited under conditions very similar to those proposed for the burrow mottled subfacies.

\section{ACKNOWLEDGMENTS}

The following New Zealand Geological Survey staff gave invaluable assistance in the preparation of this paper: G. Richards (size analysis, sectioning, and photography), L. Leonard (drafting), and C. Johnstone (typing). We extend to them our grateful thanks.

\section{REFERENCES}

Berger, W. H. and von Rad, U., 1972. Cretaceous and Cenozoic sediments from the Atlantic Ocean: In Hayes, D. E., Pimm, H. C., et al., Initial Reports of the Deep Sea Drilling Project, Volume 14: Washington (U.S. Government Printing Office), p. 787-954.

Burns, R. E., Andrews, J. E., et al., 1973. Initial Reports of the Deep Sea Drilling Project, Volume 21: Washington (U.S. Government Printing Office).

Christoffel, D. A. and Falconer, R. K. H., 1972. Marine magnetic measurements in the southwest Pacific Ocean and the identification of new tectonic features. In Hayes, D. E.
(Ed.) Antarctic oceanology II: The Australian-New Zealand Sector, Antarctic Res. Ser., 19: Washington (Am. Geophys. Union), p. 197-209.

Greenwood, R., 1973. Cristobalite: Its relationship to chert formation in selected samples from the Deep Sea Drilling Project: J. Sediment. Petrol., v. 43, p. 700-708.

Hayes, D. E. and Ringis, J., 1973. Sea floor spreading in the Tasman Sea: Nature, v. 243, p. 454-458.

Kingma, J. T., 1971. Geology of Te Aute Subdivision: New Zealand Geol. Surv. Bull. 70.

Lillie, A. R., 1953. The geology of the Dannevirke Subdivision: New Zealand Geol. Surv. Bull. 46.

Lisitzin, A. P., 1972. Sedimentation in the world ocean: Soc. Econ. Paleontol. Mineral. Spec. Publ. 17, Tulsa, Oklahoma.

Luyendyk, B. P., Davies, T. A., et al., 1972. Site 258, Unpublished Hole Summaries Leg 26, Deep Sea Drilling Project.

MacPherson, E. O., 1952. The stratigraphy and bentonitic shale deposits of Kekerangu and Blue slip, Marlborough: New Zealand J. Sci. Technol. Ser. B., v. 33, p. 258-286.

Summerhayes, C. P., 1969. Marine geology of the New Zealand Subantarctic sea floor: New Zealand Oceanog. Inst. Mem. 50.

Webb, P. N., 1971. New Zealand Lare Cretaceous (Haumurian) foraminifera and stratigraphy: A summary: New Zealand J. Geol. Geophys., v. 14, p. 795-828.

Weissel, J. K. and Hayes, D. E., 1972. Magnetic anomalies in the southeast Indian Ocean. In Hayes, D. E. (Ed.), Antarctic Oceanology II: The Australian-New Zealand Sector, Antarctic Res. Ser., 19: Washington (Am. Geophys. Union). p. 165-196. 